\title{
Teaching Sustainability: A Multidisciplinary Approach
}

\author{
Yosef Jabareen \\ Faculty of Architecture and Town Planning, Technion-Israel Institute of Technology, Haifa, Israel. \\ Email: jabareen@technion.ac.il \\ Received June 22 $2^{\text {nd }}, 2011$; revised July $30^{\text {th }}$, 2011; accepted August $10^{\text {th }}, 2011$.
}

\begin{abstract}
Sustainable development is multidisciplinary concept in its nature and is covered by various bodies of sciences. Yet, its literature is fragmented and each specific discipline of knowledge analyzes it and teaches it from its narrow perspective. Therefore, this paper suggests a new conceptual framework for teaching sustainability that assumes the multidisciplinary nature of sustainability. This framework is consists of ten concepts, a distinctive theme, and each one represents a specific domain or field that is related to sustainability. The themes represent the ethical, social, economic, ecological, spatial, design, and political aspects of sustainability. The ten conceptsare intertwined and interconnected and together they construct the holistic scene of understanding and teaching sustainability. These concepts are very useful for teaching sustainability. Moreover, each concept could be in-depth discussed individually in a specific class session. Each discipline could take advantage of this framework and may emphasize various aspects accordingly.
\end{abstract}

Keywords: Sustainable Development, Pedagogy, Teaching, Theory, Holistic

\section{Introduction}

The knowledge of sustainable development is multidisciplinary in its nature and is covered by various bodies of sciences. In recent years, 'sustainable development' has become a central theme of the world environmental discourse, while challenging academic, public, private and civil spheres. As a result, sustainable development poses a challenge for pedagogy in all fields. As for its nature, sustainable development should not be treated monolithically in the educational system but in a more holistic manner. Truly, Cortese (2006: p. 5) suggests, "Designing a sustainable human nature requires a paradigm shift toward a systemic perspective emphasizing interdisciplinary understanding, collaboration, and cooperation that must be led by higher education.” Yet, a striking weakness of the scholarship on the subject is its lack of multifaceted theorizing and the fact that it typically overlooks the multidisciplinary and complex nature of sustainability. Therefore, this paper aims to present a conceptual framework for teaching sustainability in various disciplines. The framework is composed of various concepts, where all of them present a holistic view of sustainability. This paper suggests an interdisciplinary approach for learning sustainability.

\section{Methodology}

A conceptual analysis method was used to build the conceptual framework (Jabareen, 2009). This method is a grounded theory technique that aims "to generate, identify, and trace a phenomenon's major concepts, which together constitute its theoretical framework” (Jabareen, 2009). Each concept possesses its own attributes, characteristics, assumptions, limitations, distinct perspectives, and specific function within the conceptual framework. The methodology delineates the following stages in conceptual framework building: a) mapping selected data sources; b) reviewing the literature and categorizing the selected data; c) identifying and naming the concepts; d) deconstructing and categorizing the concepts; e) integrating the concepts; f) synthesis, resynthesis, and making it all make sense; g) validating the conceptual framework; and h) rethinking the conceptual framework (Jabareen, 2009). The conceptual framework has been developed through an extensive interdisciplinary literature of sustainability. Together, these concepts form the conceptual framework for the pedagogy method, with each concept representing distinctive aspects of sustainability theory.

\section{The Theoretical Framework for Teaching}

Jabareen (2006, 2004) suggests seven concepts that together assemble the theoretical framework of 'sustainable development' and each concept represents distinctive meanings of the theoretical framework. Each concept represents distinctive meanings and aspects of the theoretical foundations of sustainability.

\section{Concept 1. The Ethical Paradox}

This concept represents the paradox between "development" and "sustainability", and evaluates the levels of the plan intervention on natural resources, such as land consumption. On one hand, we seek to maintain indefinitely the urban natural capital stock. On the other hand, however, development is environmental modification that requires intervention in nature and exhausts natural resources. This concept comes to illuminate the intervention levels of the plan on the natural assets. The paradoxical relations between sustainability and development are related to a varied spectrum of ideologies, which ranges between two extreme ethical concepts: the 'domination of nature' and the 'intrinsic right of nature.' There are two criteria.

\section{Concept 2. The Natural Capital}

Natural capital stock is "the stock of all environmental and natural resource assets, from oil in the ground to the quality of soil and groundwater, from the stock of fish in the ocean to the capacity of the globe to recycle and absorb carbon" (Pearce, Barbier, \& Markandya, 1990). Natural capital representsthe consumption level of the environmental and natural resource assets that is used for development. Keeping constant natural capital is an important criterion for sustainability. Pearce and Turner (1990: p. 44) point out that "the resource stock should 
be held constant over time.” The stock of natural capital should not decrease in order not to endanger the opportunities of future generations to generate wealth and well-being and in order not to harm the ecological system. Several efforts at measuring the planet's stock of natural capital have been proposed (Pearce, Barbier, \& Markandya, 1990; Neumayer, 2001; Geldrop \& Withagen, 2000; England, 1998; Costanza et al., 1997).

\section{Concept 3. The Utopian Vision of Sustainability}

This theme demonstrates the visionary aspects of planning regarding the discourse of on future urban life and the contribution of the city to the climate change adaptation efforts. The utopian concept envisages human cities and communities based generally on better life and mitigation of the environmental crisis. The power of utopian thinking is its inherent ability to see the future in terms of radically new forms and values (Geus, 1999). This theme represents the urban utopia of the plan and its framing discourse. And asks what is the alternative ecological urban visionary picture that the plan suggests for the city. How does it connect with the new global discourse? "Collective action frames are constructed in part as movement adherents negotiate a share understanding of some problematic condition or situation they define as in need of change, make attributions regarding who or what it to blame, articulate an alternative set of arrangements, and urge others to act in concert to affect change” (Benford \& Snow, 2000).

\section{Concept 4. Equity}

The concept of equity represents the social aspects of sustainabilityand it analyzes the environmental, economic and social justice of the plan including its procedural justice: public participation. It is perceived that a more equitable distribution of power and resources would contribute to improvement in environmental quality and injustice and a greater power inequality leads to greater environmental degradation (Boyce, Klemer, Templet, \& Willis, 1999; Agyeman, Bullard, \& Evans, 2002; Jabareen, 2005; Solow, 1991; Stymneand Jackson, 2000). The impacts of climate change and its mitigation policies are "socially differentiated" and are matter of local and international a matter of distributional equity and justice (Adger, 2001; O’Brien et al., 2004; Paavola \& Adger, 2006). Climate change has been already lead to changes in ecological, spatial, and socio-economic systems. Importantly, there are individuals and groups within all societies that have insufficient capacity to adapt to climate change. "Vulnerability to climate change refers to the propensity of human and ecological systems to suffer harm and their ability to respond to stresses imposed as a result of climate change effects" IPCC (2007: p. 720). Notably, the vulnerability of a society is influenced by its development path, physical exposures, the distribution of resources, prior stresses, social networks, government institutions, and technology IPCC (2007: pp. 719-720). And communities have different vulnerabilities within each country (O’Brien et al., 2004).

\section{Concept 5. Uncertainty Management}

This concept is about adaptation management and risk management. Recent evidences indicate that climate change is accelerating and will lead to wide-ranging shifts in climate parameters, and it "poses novel risks often outside the range of experience, such as impacts related to drought, heatwaves, accelerated glacier retreat and hurricane intensity" (IPCC, 2007: p. 719). Eventually, Climate change creates new uncertainties. "Uncertainty is a perceived lack of knowledge, by an individual or group, which is relevant to the purpose or action being undertaken and its outcomes" (Abbott, 2009). Environmental uncertainty arises from the changing social, economic, and physical environment and is experienced by everyone, andexternal uncertaintiesarise from the external environment (Abbott, 2009). They relate to external processes and events which may affect the planning process and the urban environment being planned. The challenge is to be more aware of the new and unconventional uncertainties of the climate change, which pose a new challenge to humanities. Apparently, we need better understanding of the risks facing communities, households, and urban physical infrastructure; the potential impacts on household well-being and social outcomes; and how to effectively lower community, household, and urban vulnerability (Heltberg, Bennett, \& Jorgensen, 2009; IPCC, 2007; UNDP, 2002; Adger et al., 2007; Stern, 2006; UNFCCC, 2007). In this case, there are tow types of uncertainty management, adaptation management, or risk management: a) Ex-ante management, which includes prevention or risk reduction-actions to reduce the probability of risky events (e.g., emissions reductions). b) Ex- post management includes Risk coping-actions taken to make up for losses after realization of a risky event (Mirfenderesk \& Corkill, 2009).

\section{Concept 6. The Eco-Form}

This concept evaluates the aspects of spatial planning, architecture, design, and ecologically-desired form of the city and its communities. The physical form of city affects habitat, ecosystem, daily-life activities and spatial practices of inhabitants, and eventually the climate change. Contemporary urban form has been perceived as a source of environmental problems (Alberti et al., 2003; Beatleyand Manning, 1997; EPA, 1989; Jabareen, 2006; Wheeler, 2002; Elkin, McLaren, \& Hillman, 1991). Jabareen (2006) suggests a distinctive set of seven concepts by which human habitat can be classified in terms of their "environmental burden” and develops a Sustainable Urban Form Matrix that contribute to our evaluation of the sustainability of a given form. Jabareen (2006) concludes that by using the right scales of the proposed concepts we might be enabled to produce practically the most sustainable urban forms that contribute to the climate change adaptation strategies. Therefore, the ideal sustainable urban form according to these concepts is that which has a high density and adequate diversity, compact with mixed land-uses, and its design is based on sustainable transportation, greening and passive solar energy. The concept of Urban Form Matrixis composed of seven criteria as follows:

1) Compactness: it refers to urban contiguity and connectivity and suggests that future urban development should take place adjacent to existing urban structures (Jenks, 2000). Compactness of urban space can minimize transport of energy, water, materials, products, and people (Cervero, 2003). Intensification, a major strategy for achieving compactness, uses urban land more efficiently by increasing the density of development and activity. It includes: development of previously undeveloped urban land; redevelopment of existing buildings or previously developed sites; subdivisions and conversions; and additions and extensions (Clercq \& Bertolini, 2003).

2) Sustainable Transport: in order to achieve ST the Plan should address the following criteria: shortens trips; reducing negative of traffic; encouraging non-motorized travel: walking and cycling; safe; transit-oriented development; minimizes the use of land; provides equitable access for people and their goods in each generation; and is powered by renewable energy 
sources (Duncan \& Hartman, 1996; Elkin, McLarenand Hillman, 1991; Walker \& Rees, 1997; Newmanand \& Kenworthy, 1989).

3) Density: it is the ratio of people or dwelling units to land area. Density affects climate change through differences in the consumption of energy, materials, and land for housing, transportation, and urban infrastructure, and high density can save significant amounts of energy (Parker, 1994; Van \& Senior, 2000).

4) Mixed Land Uses: indicates the diversity of functional land uses such as residential, commercial, industrial, institutional, and transportation. It allows compatible land uses to locate in close proximity to one another and thereby decrease the travel distances between activities, encourage walking and cycling; and it reduces the probability of using a car for commuting, shopping, and leisure trips, since jobs, shops, and leisure facilities are located nearby (Thorne \& Filmer-Sankey, 2003; Wheeler, 2002).

5) Diversity: Diversity is "a multidimensional phenomenon" that promotes further desirable urban features, including greater variety of housing types, building densities, household sizes, ages, cultures, and incomes (Owens, 1992; Thomas, 2003). Diversity is vital for cities and without it, the urban system declines as a living place (Jacobs, 1961) and then homogeneity of built forms, which is often produces unattractive, monotonous urban landscapes, lead to increased segregation, driving, congestion, and air pollution (Yanns, 1998).

6) Passive Solar Design: The idea of solar design is to reduce the demand for energy and to provide the best use of passive energy through specific planning and design measures, such as sitting, orientation, layout, and landscaping. This can make the optimum use of solar gain and microclimatic conditions to minimize the need for space heating or cooling of buildings by conventional energy sources (Beatley \& Manning, 1998; Swanwick, Dunnett, \& Woolley, 2003). Yannis (1998: p. 43) summarizes some design parameters for improving urban microclimate: a) Built form-density and type, to influence airflow, view of sun and sky, and exposed surface area; b) Street canyon - width-to-height ratio and orientation, to influence warming and cooling processes, thermal and visual comfort conditions, and pollution dispersal; c) Building design-to influence building heat gains and losses; d) Urban materials and surfaces finish - to influence absorption, heat storage, and emissivity; e) Vegetation and bodies of water - to influence evaporative cooling processes on building surfaces and/or in open spaces; and f) Traffic-reduction, diversion, and rerouting to reduce air and noise pollution and heat discharge.

7) Greening: Greening the city contribute positively to the climate change. It aims to bring nature into the city and has many benefits: contributions to maintenance of biodiversity; amelioration of the physical urban environment, moderating the urban climate; increasing the economic attractiveness of a city; fostering community pride; contributing to health and to education and an educational function as a symbol or representation of nature (Dumreicher, Richard, \& Ernest, 2000; Beer, Delshammar \& Schildwacht, 2003; Roger, 1999; Johnson, 2009).

\section{Concept 7. The Integrative Concept}

The integration of environmental, social, and economic concerns in planning and holistic management approaches is essential for achieving sustainability. The integrative approach seeks to bring together all stakeholders: civil society organizations, communities, and various social groups. Addressing the risk associated with climate change generally requires dealing with scenario uncertainty. Apparently, "the ability of a governance system to adapt to uncertain and unpredicted conditions is a new notion” (Mirfenderesk \& Corkill, 2009: p. 152). adaptive management requires new planning strategies and procedures beyond conventional planning approaches since this type of planning is undertaken in a high level of uncertainty, and should integrate uncertainties to planning processes, and it suppose to meet stakeholders expectations in an uncertain environment. Therefore, "adaptive governance need to be investigated at a number of levels and dimensions, for instance at policy level, planning level, implementation, administration, etc. Strategists need to design plans that not only address the environmental, economic and social needs today but also plans that are flexible enough to quickly adapt to our rapidly changing environment" (Johnson, 2009).

\section{Concept 8. Ecological Energy}

The clean, renewable, and efficient use of energy is a central theme in planning for the achievement of climate change objectives. This concept evaluates how a plan a major and fundamental condition for sustainability. This theme addresses the energy sector and whether it proposes strategies to reduce energy consumption and to use new, alternative, and clean energy sources.

\section{Concept 9. The Ecological Economics Theme}

This theme assumes that environmentally sound economics could be a decisive driven force for achieving sustainability in a capitalist world. For example, it appears that President Barack Obama is trying to combat a recession and job losses with a huge ramp-up in green-energy spending. Obama's goal is to generate new jobs while simultaneously transforming the energy marketplace, heading off global warming, and building a U.S. clean-energy economy and industry. His energy spending marks a sharp departure from the past 25 years, both in quantity and focus. Climate-change legislation is a big part of his program. A "market-based cap on carbon pollution" would drive the production of more renewable energy in America, he said, promising to invest $\$ 15$ billion annually for 10 years to support energy innovation leading to new technologies such as "wind power and solar power, advanced biofuels, clean coal, and more fuel-efficient cars and trucks built right here in America." "The American Recovery and Reinvestment Plan signed by the President will spur job creation while making long-term investments in energy, and infrastructure. Among other objectives, the recovery plan will increase production of alternative energy". Obama said that in order "to truly transform our economy, protect our security, and save our planet from the ravages of climate change, we need to ultimately make clean, renewable energy the profitable kind of energy” (Yanns, 1998).

\section{Concept 10. Politics of Sustainability}

This themepresents the concept of global agenda,or our 'all agenda', as an emerging new worldwide political discourse reconstituted around the ideas of sustainability. Since the Rio Summit, this discourse has extended beyond purely ecological concepts to include various international issues, such as security, peace, trade, heritage, hunger, shelter, and other basic services. Simultaneously, this concept reflects deep political disputes between various countries, such as developed and developing countries, which undermines the achievability of sustainability. 


\section{Conclusion}

1) This paper suggests a new conceptual framework for teaching sustainability. The main features of this framework are as follows:

2) This framework is consists of ten concepts, and each one represents a specific domain or field that is related to sustainability.

3) The concepts represent the ethical, social, economic, ecological, spatial, design, and political aspects of sustainability.

4) The conceptual framework with its ten themes altogether tells the story of sustainable development. The ten themes are intertwined and interconnected and together they construct the holistic scene of understanding sustainability.

5) The conceptual framework with its ten cocnepts could be used to assess public policies and projects from a sustainability perspective.

6) Each theme could be in-depth discussed individually in a specific class session.

7) Each discipline could take advantage of this framework and may emphasize various aspects accordingly.

\section{References}

Abbott, J. (2009). Planning for complex metropolitan regions: A better future or a more certain one? Journal of Planning Education and Research, 28, 503-517. doi:10.1177/0739456X08330976

Adger, W. N., Agrawala, S., Mirza, M. M. Q., Conde, C., O’Brien, K., Pulhin, J., Pulwarty, R., Smit, B., \& Takahashi, K. (2007). Assessment of adaptation practices, options, constraints and capacity. In M. L. Parry, O. F. Canziani, J. P. Palutikof, P. J. van der Linden and C. E. Hanson (Eds.), Climate Change 2007: Impacts, Adaptation and Vulnerability. Contribution of Working Group II to the Fourth Assessment Report of the Intergovernmental Panel on Climate Change (pp. 717-743). Cambridge, UK: Cambridge University Press.

Adger, W. N. (2001). Scales of governance and environmental justice for adaptation and mitigation of climate change. Journal of International Development, 13, 921-931. doi:10.1002/jid.833

Agyeman, J., Bullard, R. D., \& Evans, B. (2002). Exploring the nexus: Bringing together sustainability, environmental justice and equity. Space \& Polity, 6, 77-90. doi:10.1080/13562570220137907

Alberti, M. (2000). Urban form and ecosystem dynamics: Empirical evidence and practical implications. In K. Williams, E. Burton, and M. Jenks (Eds.) Achieving Sustainable Urban Form (pp. 84-96). London: E \& FN Spon.

Alberti, M., Booth, D., Hill, K., Coburn, B., Avolio, C., Coe, S., \& Spirandelli, D. (2003). The impacts of urban patterns on aquatic ecosystems: An empirical analysis in Puget Lowland Sub-Basins. Seattle: Department of Urban Design and Planning, University of Washington.

http://www.cfr.washington.edu/research.urbaneco/student_info/class es/Aut2003/Fall_2003_readings/alberti_et_all03_LE.pdf

Beatley, T., \& Manning, K. (1998). The ecology of place: planning for environment, economy and community. Washington, DC: Island Press.

Beer, A., Delshammar, T., \& Schildwacht, P. (2003). A changing understanding of the role of greenspace in high-density housing: A European perspective. Built Environment, 29, 132-143. doi:10.2148/benv.29.2.132.54468

Benford, R. D., \& Snow, D. A. (2000). Framing processes and social movements: An overview and assessment. Annual Review of Sociology, 26, 611-639. doi:10.1146/annurev.soc.26.1.611

Boyce, J. K., Klemer, A. R., Templet, P. H. \& Willis, C. E. (1999). Power distribution, the environment, and public health: A state-level analysis. Ecological Economics, 29, 127-140. doi:10.1016/S0921-8009(98)00056-1

Cervero, R. (2003). Coping with complexity in America's urban transport sector. The 2nd International Conference on the Future of Urban Transport. Göteborg, Sweden.
Clercq, F., \& Bertolini, L. (2003). Achieving sustainable accessibility: An evaluation of policy measures in the Amsterdam area. Built Environment, 29, 36-47. doi:10.2148/benv.29.1.36.53949

Cortese, A. (2003). Higher education and sustainability. In W. M. Timpson, B. Dunbar, G. Kimmel, B. Bruyere, P. I. Vewman and H. Mizia (Eds.), 147 Practical Tips for Teaching Sustainability: Connecting the Environment, the Economy, and Society (p. 5). Madison, Wisconsin: Atwood Publishing.

Costanza, R., D’Arge, R., De Groot, R., Farber, S., Grasso, M., Hannon, B., Limburg, K., Naeem, S., O’Neill, R. V., Paruelo, J., Raskin, R. G., Sutton, P., \& Van den Belt, M. (1997). The value of the world's ecosystem services and natural capital. Nature, 387, 253-260. doi: $10.1038 / 387253 \mathrm{a} 0$

Dumreicher, H., Levine, R. S., \& Yanarella, E. J. (2000). The appropriate scale for "low energy": Theory and practice at the Westbahnhof. In S. Koen and S. Yannas (Eds.), Architecture, City, Environment. Proceedings of PLEA 2000 (pp. 359-363). London: James \& James.

Duncan, B., \& John, H. (1996). Sustainable urban transportation initiatives in Canada. Paper submitted to the APEC Forum on Urban Transportation. Seoul, Korea.

Elkin, T., McLaren, D., \& Hillman, M. (1991). Reviving the city: Towards sustainable urban development. London: Friends of the Earth.

England, R. (1998). Should we pursue measurement of the natural capital stock? Ecological Economics, 27, 257-266. doi:10.1016/S0921-8009(98)00026-3

EPA-United States Environmental Protection Agency (2001). Our built and natural environments: A technical review of the interactions between land use, transportation, and environmental quality. EPA 231-R-01-002. http://www.smartgrowth.org

Forman, R. T. (2002). The missing catalyst: Design and planning with ecology. In B. T. Johnson and K. Hill (Eds.), Ecology and Design: Frameworks for Learning. Washington, DC: Island Press.

Geldrop, J., \& Withagen, C. (2000). Natural capital and sustainability. Ecological Economics, 32, 445-455.

Geus, M. (1999). Ecological utopias: Envisioning the sustainable society. International Books. Utrecht, The Netherlands.

Heltberg, R., Paul, B. S., \& Steen L. J. (2009). Addressing human vulnerability to climate change: Toward a 'no-regrets' approach. Global Environmental Change, 19, 89-99.

IPCC, Schneider, S. H., Semenov, S., Patwardhan, A., Burton, I., Magadza, C. H. D., Oppenheimer, M., Pittock, A. B., Rahman, A., Smith, J. B., Suarez, A., \& Yamin, F. (2007). Assessing key vulnerabilities and the risk from climate change. In M. L. Parry, O. F. Canziani, J. P. Palutikof, P. J. van der Linden and C. E. Hanson (Eds.), Climate Change 2007: Impacts, Adaptationand Vulnerability. Contribution of Working Group II to the Fourth Assessment Report of the Intergovernmental Panel on Climate Change (pp. 779-810). Cambridge, UK: Cambridge University Press.

Jabareen, Y. (2004). A knowledge map for describing variegated and conflict domains of sustainable development. Journal of Environmental Planning and Management, 47, 623-642.

Jabareen, Y. (2004). Building conceptual framework: Philosophy, definitions and procedure. International Journal of Qualitative Methods, 8, 49-62.

Jabareen, Y. (2006). Sustainable urban forms: Their typologies, models, and concepts. Journal of Planning Education and Research, 26, 38-52.

Jenks, M. (2000). The acceptability of urban intensification. In K. Williams, E. Burton and M. Jenks (Eds.), Achieving Sustainable Urban Form. London: E \& FN SPON.

Johnson, J. (2009) Buying a sustainable economy: The record recovery act energy spending may trigger a new clean-energy industry. Chemical \& Engineering News, 87, 17-22.

Mirfenderesk, H., \& Corkill, D. (2009). Sustainable management of risks associated with climate change. International Journal of Climate Change Strategies and Management, 1, 146-159.

Neumayer, E. (2001). The human development index and sustainability. A constructive proposal. Ecological Economics, 39, 101-114.

Newman, P., \& Kenworthy, J. (1989). Gasoline consumption and cities: A comparison of US cities with a global survey. Journal of the American Planning Association, 55, 23-37.

O’Brien, K., Leichenko, R., et al. (2004). Mapping vulnerability to multiple stressors: Climate change and globalization in India. Global Environmental Change, 14, 303-313. 
Owens, S. (1992). Energy, environmental sustainability and land-use planning. In M. Breheny (Ed.), Sustainable Development and Urban Form (pp. 79-105). London: Pion.

Paavola, J., \& Adger, W. N. (2006). Fair adaptation to climate change.

Ecological Economics, 56, 594-609.

Parker, T. (1994). The land use-air quality linkage: How land use and transportation affect air quality. Sacramento: California AirResources Board.

Pearce, D., Barbier, E., \& Markandya, A. (1990). Sustainable development: Economics and environment in the third world. London: Earthscan Publications.

Pearce, D., \& Turner, R. K. (1990). Economics of natural resources and the environment. Baltimore: Johns Hopkins University Press.

Solow, R. (1991). Sustainability: An Economist's perspective. The eighteenth J. Seward Johnson lecture. Woods Hole, MA: Woods Hole Oceanographic Institution.

Stern, N. (2006). The stern review on the Economics of Climate Change. HM Treasury, UK: Cambridge UniversityPress.

Stymne, S., \& Jackson, T. (2000). Intra-generational equity and sustainable welfare: A time series analysis for the UK and Sweden. Ecological Economics, 33, 219-236.

Swanwick, C., Nigel, D., \& Woolley, H. (2003). Nature, role and value of green space in towns and cities: An overview. Built Environment, 29, 94-106. doi:10.2148/benv.29.2.94.54467

Turner, S. R. S., \& Murray, M. S. (2001). Managing growth in a cli- mate of urban diversity: South Florida's Eastward ho! Initiative. Journal of Planning Education and Research, 20, 308-328. doi:10.1177/0739456X0102000304

Thomas, R. (2003). Building design. In R. Thomas and M. Fordham (Eds.), Sustainable Urban Design: An Environmental Approach (pp. 46-88). London: Spon Press.

Ulrich, R. S. (1999). Effects of gardens on health outcomes: Theory and research. In C. C. Marcus, And M. Barnes (Eds.), Healing Gardens: Therapeutic Benefits and Design Recommendations. New York: Whiley.

UNDP-United Nations Development Programme (2002). Human development report 2002: Deepening democracy in a fragmented world. New York: Oxford University Press.

UNFCCC - United Nations Framework Convention on Climate Change (2007). Climate Change: Impacts, Vulnerability and Adaptation in Developing Countries. http://unfccc.int

Walker, L., \& Rees, W. (1997). Urban density and ecological footprints -An analysis of Canadian households. In R. Mark (Ed.), Eco-City Dimensions: Healthy Communities, Healthy Planet. Gabriola Island: New Society Publishers.

Wheeler, S. M. (2002). Constructing sustainable development/safeguarding our common future: Rethinnking sustainable development. Journal of the American Planning Association, 68, 110-111.

Yanns, S. (1998). Living with the city: Urban design and environmental sustainability. In M. Eduardo and S. Yannas (Eds.), Environmantly Friendly Cities (pp. 41-48). London: James \& James. 